\title{
Learning of Cross-Cultural Based Writing Skill in The English Camp Program (ECP) of English Education Department
}

\author{
Moh. Hafidz \\ STKIP PGRI Bangkalan \\ mohhafidz@stkippgri-bkl.ac.id \\ Maulana Yusuf Aditya \\ STKIP PGRI Bangkalan \\ aditya@stkippgri-bkl.ac.id
}

\begin{abstract}
Learning of cross cultural based writing skills is the process of conveying different cultural values to be consciously understood and presented in written text. The purpose of the research is to convey and apply the new culture of various national capitals in learning writing skills. This study used a qualitative descriptive approach with a case study design, the data were collected directly by observing the activities of ECP (English Camp Program). in Mojokerto. Then, researcher analyzed the dat using content analysis of social treatment with reducing, presenting data and drawing conclusions.The result is cross-cultural based learning makes ECP participants easy to write because of the availability of a variety of theoretically and practically references. Crosscultural based learning is not a psychological problem but a very interesting scientific study to be applied into real life. Cross-cultural understanding is the main element in producing comprehensive writing skill.
\end{abstract}

Keywords: Cross-culture, real life, English and writing skills

\section{Introduction}

ECP (English Camp Program) is one of the activities of the English education Department which is carried out at the end of each semester for the second semester to improve English language skills including reading, writing, listening and speaking skills. This program is integrated with Intensive Course (IC). The program lasts for 3-4 days which is carried out off campus and is coordinated by the manager of the ESA (English Students' Association).

The annual ECP activities are English training, English talk shows, Public speaking, Debate, ESQ, Art night, Outbound and others. From each activity, each lecturer was given responsibility to accompany him even though he was accompanied by the ESA team to find out the English language skills of the ECP participants.

This year, the ECP (English Camp Program) activity is different from previous activities. The ECP program is designed with cross-culture based activities. Cross-cultural understanding is one of the requirements for communicating with people from different regions and even from different countries, especially for students who are learning English. Certainly learning about cross-cultural learning is needed, the process of cultural learning can be assisted with experience, reflection and training (Pujiyanti, U \& Zuliani, F,R, 2014). 
Hafidz, Aditya

TELL: Teaching of English Language and Literature Journal

Vol. 7, No 2, September 2019, DOI http://dx.doi.org/10.30651/tell.v7i2.3409

The cross cultural based ECP program will not only improve English language skills and understanding of new cultures but will also experience changes in self-image and will emulate new social lives, cultural behaviors and new ways of life (Catana, 2014) especially in communicating both oral and written. The ability of English especially in writing skills and understanding of cross-culture is essentially an interrelated unit (Tseng, 2017), so the writing skills learning activities in the ECP program are designed based on cross-cultural learning.

The concept of cross-cultural based writing skills learning begins with the formation of groups consisting of 5 (five) groups, the names of each group are given the names of the national capitals, namely New York, London, Manchester, Auckland and Santafe. So, before ECP Program participants take part in learning activities, all participants have been given the opportunity to access articles or information relating to the culture of their respective national capitals. Participants are automatically trained to record vocabulary and points related to the culture and make written summaries (Ekstam, 2014), and varied methods and media when ECP program activities take place, because students have often gotten difficulties such as psychological problems (culture-shock), linguistic and actual discourses (Shukri, 2014).

Therefore, researchers are interested in investigating cross-cultural based writing skills in the ECP program organized by the manager of ESA of English Education Department STKIP PGRI Bangkalan.

\section{Review of Literature}

\section{Understanding Cross-cultural Communication}

The study of culture is very broad in scope, in this case the definition used is Edward Taylor's statement in Pujianti (2014 that "culture is all forms of knowledge, beliefs, arts, morals, laws, customs, and some other abilities and habits carried out by someone in a community ". Whereas cross-cultural communication was also conveyed by several figures such as Byram, Nichols \& Stevens who argued that cross-cultural communication was "the ability to interact with others to accept different views and to be aware of different judgments" (Yano, 2006).

\section{Cross-cultural based English Learning}

Culture-based English learning is designed to encourage awareness of educators and students that language is part of culture and to improve communication skills both oral and written (Choudhury, 2014). To encourage educator awareness in developing crosscultural understanding, it is necessary to pay attention to the level of cultural knowledge: (1) personal knowledge, awareness of one's cultural beliefs and practices; (2) popular knowledge, awareness of dominant culture; (3) school knowledge, awareness of institutional decisions, such as textbook choices; and (4) transformative knowledge, crosscultural awareness, and interactions that can be culturally responsible (Ikpeze, 2015). In addition, the role of educators in cross-cultural based English learning is as a facilitator of the learning process, organizers, and lifelong students / students (Zhu, 2010; Zhu, 2010).

To improve written communication skills in learning English, it is necessary to integrate matters relating to language, culture, material, (Choudhury, 2014) media and classroom management into language learning outcomes. Strengthening students' understanding of new cultures and improving writing skills must be obtained through enrichment of literature both outside and in the learning process (Buttaro, 2004). From a variety of literature obtained, students will automatically understand cross-culture as a reference in writing. In addition to improving written communication skills, cross-cultural 
based English learning can also improve cognitive and social abilities in expressing, interpreting and negotiating meaning (Yano, 2006).

\section{Learning of Cross-Cultural based Writing Skills}

Writing skill is one way to communicate ideas in text form to the reader. Writing is a complex skill because it requires a comprehensive learning process and writing format such as grammar, vocabulary, content, mechanics, cohesion, coherence and others (Shukri, 2014). In learning of cross-cultural based writing skills include: (1) Integrating all tasks into language skills, (2) sources of information that are meaningful, relevant, and diverse as input that is easily understood, (3) meaningful and organized context for comprehensive results ; and (4) clear guidelines and criteria for group work and group evaluation (Tseng, 2017). Meanwhile, to improve writing skills, it requires the activity to record the reading results from actual sources into special notes if needed as a written reference, but also requires a summary from one to two sentences, the summary includes: material, topic, position, arguments, points and conclusions (Ekstam, 2014). So, crosscultural based writing skills are strongly influenced by the learning process and the source of knowledge that we accessed.

\section{Research Method}

The research design was a case study. The selection of the design is to reveal contemporary events that are in a natural context. This nature causes the case study research design to be very precise to explain a complex natural condition (Wardani, 2013) such as learning about cross-cultural based writing skills in the ECP (English Camp Program) English Education Department of STKIP PGRI Bangkalan. This design is used as a procedure to identify and describe the attitudes of students and lecturers in the second semester of the 2018/2019 academic year.

Data collection used content analysis of social treatment in this study. Content analysis of social treatment is used to collect types of data regarding learning activities based on crosscultural writing skills using the observation method. Through the method of data collection above, researcher obtained the qualitative data. Then, data were analyzed in a descriptive qualitative. These activities include data reduction, data display, and drawing conclusions or verification.

\section{Result and Discussion}

\section{Understanding Cross-cultural Communication}

Tutors designs cross-cultural based learning activities in ECP (English Camp Program). ECP participants were formed into several groups according to the names of the capitals (Jakarta, New York, London, Manchester, Aukland and Santafe), then each group accessed from various literatures and presented their respective cultures in the form of knowledge, beliefs, arts, morals , law, custom, and several other abilities and habits (Pujiyanti, U \& Zuliani, F,R, 2014). The presentation is not just about delivering material, but with various media such as displaying posters, attaching cultural forms and even modeling in the form of clothing and other activities of each capital city. 


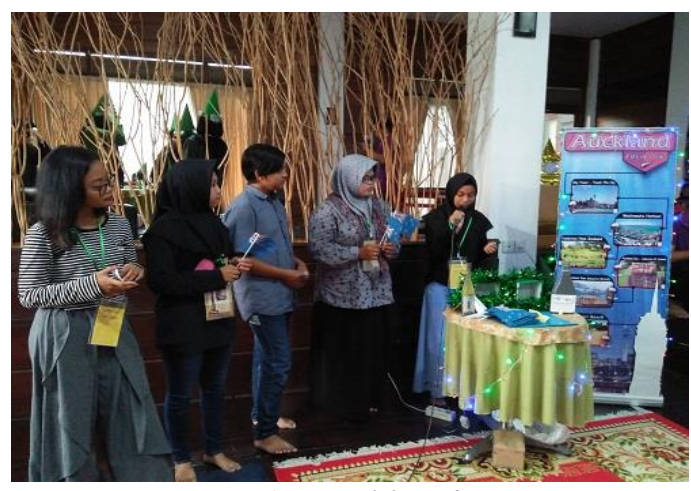

Figure 1. Auckland group Presenting New Zealands Cultures

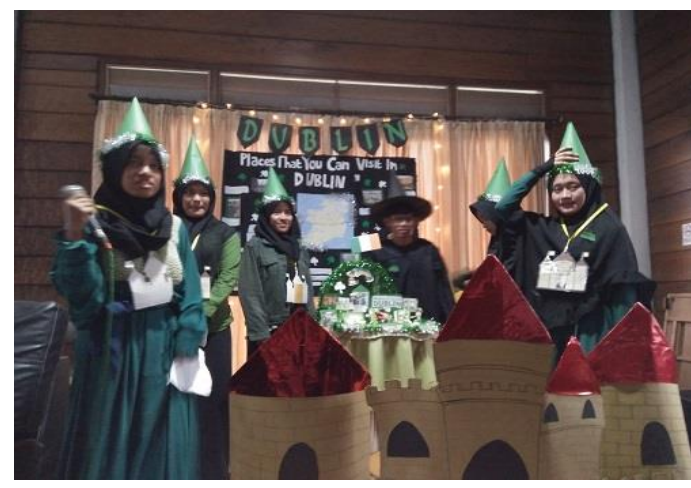

Figure 2. Doublin group Presenting Dublins Cultures

This learning activity is packaged in the form of cross-cultural storefronts. After each group has finished preparing their stationary, ECP participants observe, interview and take notes as a result of group reports in turn. From this activity students can understand cross-cultural performance in the arsitecture of buildings, culinary, fashion, habits and beliefs. It can build and get different perspectives from different cultures (Yano, 2006). Cross-cultural storefronts can socialize various cultures and sensitize ECP participants to develop cross-cultural based ideas in written form.

\section{Cross-cultural based English Learning}

English is a part of culture has become a communication tool to raise awareness about the importance of understanding across cultures and accepting it as part of life. Thus, Choudhury (2014) states thatt cross-cultural based English learning in ECP activities has noticed (1) encouraging ECP participants to discover new cultures and practice them such as classical music, opera, Notting Hill festival in London, so ECP participants understand them and describe it and even practice it, (2) the existence of unique knowledge and a reflection of the region. Like the city of Manchester, the ECP participant's knowledge is to make banners that have pictures of buildings with unique architecture and in the form of towers, (3) the needs of the study program and curriculum. In this case, tutors and ECP participants realized that this activity was part of the Intensive Course (IC) course, to improve English language skills including speaking, reading, listening and writing. So this activity uses the tagline "the limits of my language are the limits of my world", (4) the knowledge obtained is easy to apply in everyday life. The knowledge possessed in ECP activities can be applied in the form of culinary tourism, the use of cultural attributes in certain festivals and art as explained earlier. In addition, ECP participants are also equipped with cross-cultural understanding in real life such as eating, bathing and so on (Ikpeze, 2015). 


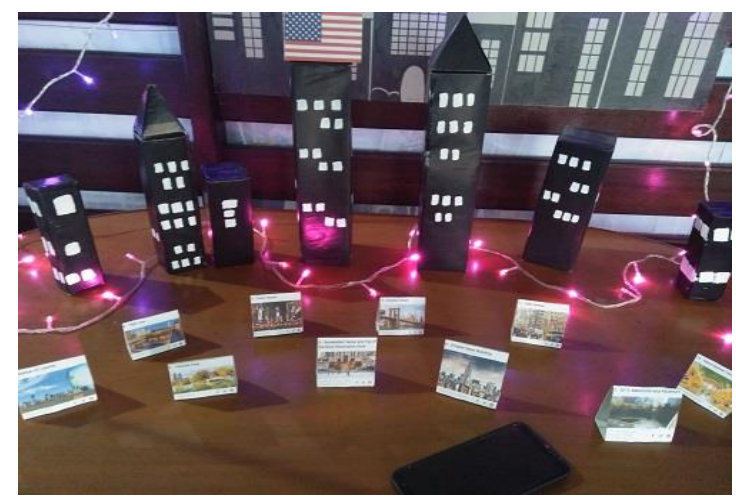

Figure 3

Storefronts of cultures

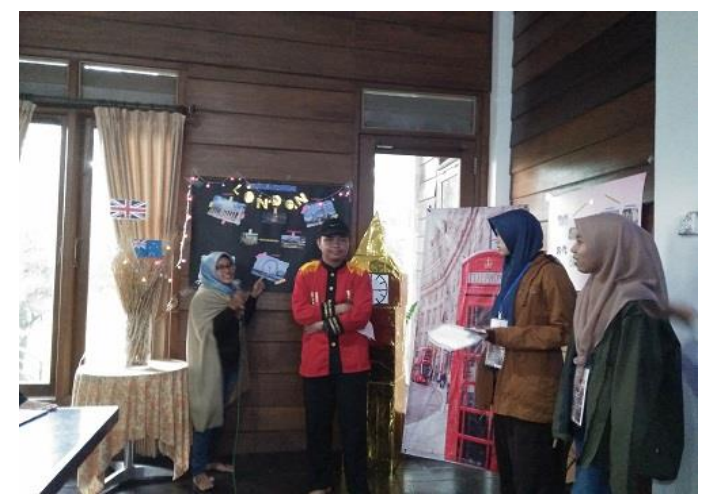

Figure 4

Observation and interview

Therefore, learning English related across cultures can make it easier for ECP participants to communicate in English specially on writing skills, because ECP participants are automatically encouraged to access various references in writing, enrichment of knowledge and experience in social life (Buttaro, 2004).

\section{Cross-Cultural based Writing Skills Learning}

The results of reading various literatures, observations of cultural storefronts and structurally interviews, participants of ECP activities are able to express cross-cultural ideas into written text (Ekstam, 2014) dengan cara: considering : The first, making all activities that examine cultural diversity as a reference to the contents of writing. The second, the suitability of references to topics that have been determined and easily understood both within their own groups and other groups, because the references used reflect about each city such as Melbourne streat art, Fiesta in Mexico, Whitehouse in London and outside culture that have become parts of daily life, such as how to eat, how to defecate and others.

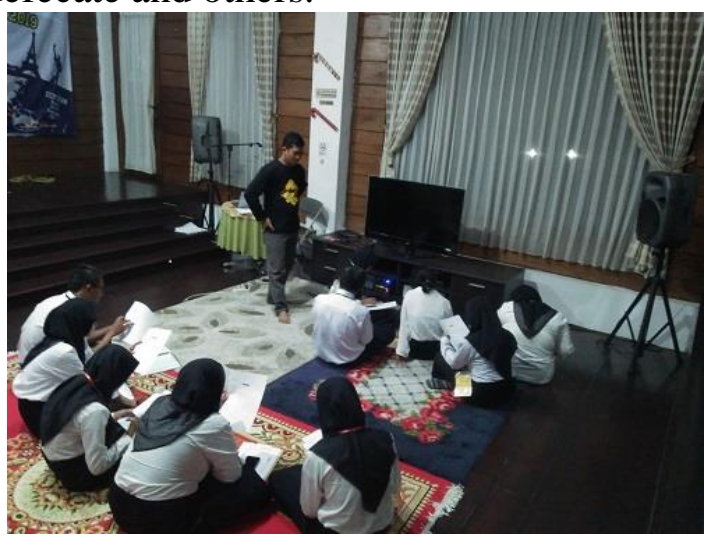

Figure 5

Group work

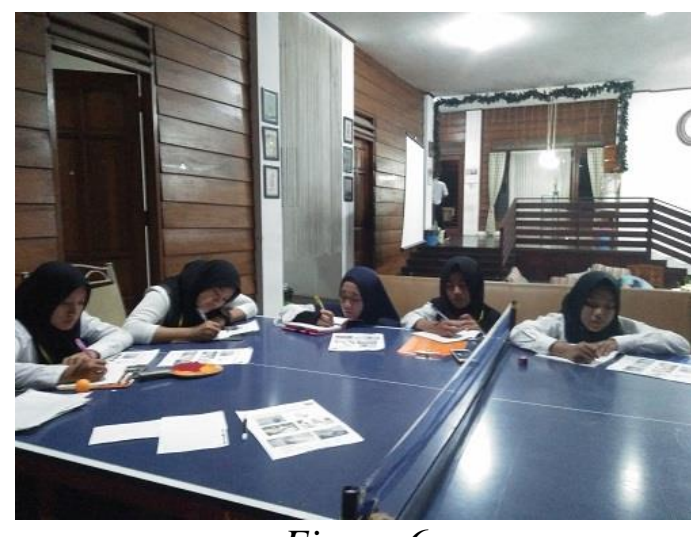

Figure 6

Individual work

The third, the content of the text communicates between knowledge and real life such as making essays about the difference between a sitting toilet with a squat toilet and others (Tseng, 2017), and (4) emphasizing a comprehensive writing which includes grammar, vocabulary, content, mechanics, cohesion, coherence and others (Shukri, 2014). In this case, there are around $30 \%$ of participants have weak score in mechanical and cohesion aspects. While there are $70 \%$ participants are good in the generally evaluation results of all aspects in writing. 
Hafidz, Aditya

TELL: Teaching of English Language and Literature Journal

Vol. 7, No 2, September 2019, DOI http://dx.doi.org/10.30651/tell.v7i2.3409

\section{Conclusion}

Understanding cross-cultural becomes a psychological problem for beginner students, especially English learners. Cross-cultural based learning is able to integrate knowledge about new cultures from various cities in the world into learning activities of writing skills oriented. From this learning cross-cultural knowledge is not a problem but a very interesting scientific study to be applied into real life. Cross-cultural understanding is the main element in drilling good writer

\section{References}

Buttaro, L. (2004). Second-Language Acquisition, Culture Shock, and Language Stress of Adult Female Latina Students in New York. Journal of Hispanic Higher Education, 37.

Catana, S. E. (2014). Teaching Cross-cultural Communication Issues - A Way of Successfully Integrating into The Multicultural Knowledge Society. Procedia social and behavioral sciences, 345 .

Choudhury, R. U. (2014). The Role of Culture un Teaching and Learning of English as Foriegn Language. Express, an International Journal of Multi Disciplinary Research, 3.

Ekstam, J. \&. (2014). A Guide for Teachers and Students in a Cross-cultural Context. Sweden: Kristianstad University Press.

Ikpeze, C. H. (2015). Teaching across Cultures Building Pedagogical Relationships in Diverse Contexts. New York: Sense Publisher.

Pujiyanti, U \& Zuliani, F,R. (2014). Cross Cultural Understanding: A Handbook To Understand Others' Cultures. Jogjakarta: CV. Hidayah.

Shukri, N. A. (2014). Second Language Writing and Culture: Issues and Challenges from the Saudi Learners' Perspective. Arab World English Journal, 192.

Tseng, C. H. (2017). Teaching "Cross-cultural Communication” through Content Based Instruction: Curriculum Design and Learning Outcome from EFL Learners' Perspectives. English Language Teaching, 33.

Wardani, K. \&. (2013). Sikap Bahasa Siswa Terhadap Bahasa Indonesia: Studi Kasus dI SMA Negeri 1 Singaraja. e-Journal Program Pascasarjana Universitas Pendidikan Ganesha, 3-4.

Yano, Y. (2006). Cross-cultural Communication and English as an International Language. Intercultural Communication Studies, 1.

Zhu, C. \&. (2010). A Cross-cultural Study of Teacher Perspectives on Teacher Roles and Adoption of Online Collaborative Learning in Higher Education. European Journal of Teacher Education, 149. 